\title{
DETERMINAN GANGGUAN KAPASITAS FUNGSI PARU-PARU PADA PERAJIN BATU BATA MERAH DI KABUPATEN BADUNG
}

\author{
I Gusti Agung Ayu Vintan Pramesti, Ni Ketut Sutiari* \\ Program Studi Sarjana Kesehatan Masyarakat Fakultas Kedokteran Universitas Udayana \\ *Email:ketut_sutiari@unud.ac.id
}

\begin{abstract}
ABSTRAK
Perajin batu bata merah merupakan pekerja sektor informal yaitu pekerja harian lepas dan borongan yang berisiko terkena gangguan kapasitas fungsi paru-paru akibat dari paparan debu saat bekerja. Tujuan penelitian ini untuk mengetahui hubungan karakteristik individu dan paparan debu dengan gangguan kapasitas fungsi paru-paru pada perajin batu bata merah di Kabupaten Badung. Desain penelitian ini yaitu analitik kuantitatif dengan metode cross-sectional study. Penentuan sampel dengan metode consecutive sampling yaitu perajin batu bata merah di Kabupaten Badung berjumlah 42 orang. Data umur, durasi kerja, masa kerja, kebiasaan merokok, dan penggunaan alat pelindung diri dikumpulkan menggunakan kuesioner, tinggi badan diukur dengan microtoise, berat badan dengan timbangan berat badan, paparan debu dengan Personal Dust Sampler (PDS), dan gangguan kapasitas fungsi paru-paru dengan spirometer. Data dianalisis secara univariabel, bivariabel dengan uji Chi-square, dan multivariabel dengan multiple logistic regression. Hasil penelitian menujukkan 92,86\% perajin mengalami gangguan kapasitas fungsi paru-paru. Analisis multivariabel menunjukkan bahwa paparan debu merupakan variabel yang paling berpengaruh terhadap gangguan kapasitas fungsi paru-paru namun signifikansi rendah ( $\mathrm{AOR}=18,18 ; \mathrm{CI}=1,02-324,8 ; \mathrm{p}=0,004)$. Sebagai upaya pencegahan gangguan kapasitas fungsi paru-paru, perajin diharapkan lebih peduli terhadap risiko yang dihadapi di tempat kerja dan melakukan upaya pencegahan.
\end{abstract}

Kata kunci: Perajin, Fungsi Paru, Debu

\section{ABSTRACT}

Red brick crafters are the informal sectors, namely daily laborers and piece workers who are at risk of lung capacity function disorders as a result of dust exposure during the work. This study's aim is to determine relationship between individual characteristics and exposure to dust with the lung capacity function disorders in red brick crafters in Badung Regency. This study's designs is quantitative analytic with cross-sectional study method. Determination sample using consecutive sampling method ( $n=42$ peoples). Data about age, daily hours of work, working period, smoking habits, and use of PPE are collected by questionnaire, height measured by microtoise, weight by spring scales, dust exposure by Personal Dust Sampler, and lung capacity function disorders with spirometer. Data is analyzed univariable, bivariable with Chi-square, and multivariable with multiple logistic regression to analyze factors that related to lung capacity function disorders. The results showed $92,86 \%$ crafters had lung capacity function disorders. Multivariable analysis showed that dust exposure correlate with lung capacity function disorders but the signification is low ( $\mathrm{AOR}=18,18 ; 95 \% \mathrm{CI}=1,02-324,8 ; \mathrm{p}=0,004)$. As an effort to prevent lung capacity function disorders, crafters should be aware of the risk on the worksite and also keep doing prevention.

Keywords: Crafters, Pulmonary Function, Dust

\section{PENDAHULUAN}

Penyakit Akibat Kerja (PAK) merupakan penyakit yang disebabkan oleh pekerjaan dan atau lingkungan kerja (Perpres RI No. 7 Tahun 2019). PAK terjadi akibat pajanan faktor fisik, kimia, biologi, ataupun psikologi pada tempat kerja. Terdapat 250 juta kasus penyakit akibat kerja yang mampu menyebabkan terjadinya
300.000 kematian di seluruh dunia dengan insiden rata-rata penyakit paru-paru akibat kerja sebesar $1: 1000$ pekerja dalam setahun. Data International Labour Organization (ILO) mengungkapkan bahwa pekerja meninggal akibat penyakit saluran pernapasan sebesar $21 \%$. Angka ini sebagai penyebab kematian pekerja nomor 3 setelah kematian pekerja 
akibat kecelakaan kerja (Septyaningrum, 2014). Berdasarkan hasil survey oleh Direktorat jenderal PPM \& PL, di Indonesia Penyakit Paru-paru Obstructive Kronis (PPOK) menempati urutan pertama penyumbang angka kesakitan (35\%), diikuti dengan asma bronchial (33\%), kanker paruparu (30\%), dan lainnya (2\%).

Penyakit pada saluran pernafasan atau gangguan kapasitas fungsi paru-paru merupakan salah satu penyakit akibat kerja yang disebabkan oleh paparan debu pada lingkungan tempat kerja. Debu merupakan partikel-partikel zat padat yang disebabkan oleh adanya kekuatan alami atau mekanisme pengolahan, penghancuran, pelembutan, pengepakan yang cepat, peledakan, dan lain-lain dari bahan organik maupun anorganik. Debu dapat menyebabkan kerusakan paru-paru dan fibrosis bila terinhalasi secara terus menerus serta menimbulkan rasa tidak nyaman pada saat bekerja yang ditandai dengan batuk, perasaan tidak nyaman, susah bernafas, napas pendek, dan lama kelamaan berakibat fatal. Pekerja yang terpapar debu secara kronis akan mengalami penurunan fungsi paru-paru yang ditandai dengan penurunan nilai pemeriksaan spirometri yaitu nilai FEV1\%, FVC\% dan FEV1/FVC\% (Mohammadien et al., 2013).

Pajanan debu khususnya debu silika secara terus menerus dapat mempengaruhi kesehatan yaitu dapat menyebabkan gangguan kapasitas fungsi paru-paru dan dalam jangka waktu yang panjang dapat menimbulkan penyakit pneumoconiosis yaitu silikosis. Gangguan kapasitas fungsi paru-paru dapat bersifat obstructive, restrictive, dan mixed restrictive obstructive. Gangguan kapasitas fungsi paru-paru terjadi secara bertahap atas proses akumulasi dari paparan debu yang masuk ke dalam paru-paru (Anugrah, 2014).

Berdasarkan Peraturan Menteri Ketenagakerjaan Republik Indonesia Nomor 5 Tahun 2018 tentang Keselamatan dan Kesehatan Kerja Lingkungan Kerja, nilai ambang batas paparan debu silika respirable yaitu sebesar $3 \mathrm{mg} / \mathrm{m} 3$. Di Indonesia, penyakit atau gangguan paruparu akibat kerja yang disebabkan oleh debu diperkirakan cukup banyak. Berdasarkan penelitian Handari et al., (2018) sebagian besar pekerja mengalami gangguan kapasitas fungsi paru-paru yaitu $54,5 \%$ dan $45,5 \%$ tidak mengalami gangguan.

Indonesia merupakan salah satu negara berkembang yang sedang melakukan pembangunan di berbagai sektor, sehingga menyebabkan banyaknya proyek-proyek konstruksi di Indonesia, tidak terkecuali di Bali yaitu Kabupaten Badung (Sholihah \& Tualeka, 2015). Sesuai dengan Peraturan Bupati Badung Nomor 9 Tahun 2019 tentang Perubahan Atas Peraturan Bupati Nomor 43 Tahun 2018 Tentang Pedoman Pemberian Hibah), Pemerintah kabupaten Badung telah menganggarkan dana hibah untuk kelompok masyarakat dan desa adat (pakraman) sesuai kebutuhan untuk pembangunan konstruksi pura ataupun banjar guna meningkatkan kesejahteraan masyarakat. Sehingga banyak proyek pembangunan di Kabupaten Badung.

Proyek konstruksi banyak menghasilkan debu dalam proses kerjanya, terlebih lagi jika mempergunakan batu bata merah sebagai materialnya. Batu bata merah terbuat dari campuran tanah dan air, 
tetapi terdapat penambahan bahan additive seperti abu sekam padi, abu ampas tebu dan fly ash (abu batu bara) pada saat proses pembakaran yang berpengaruh dalam meningkatkan nilai kuat tekan batu bata merah, namun bahan-bahan tersebut mengandung zat berbahaya seperti silika (Abdurrohmansyah et al., 2015).

Perajin batu bata merah merupakan pekerjaan sektor informal yaitu pekerja harian lepas dan borongan yang berisiko terkena gangguan kapasitas fungsi paruparu sebagai akibat dari paparan debu yang diterima saat bekerja. Hal ini sesuai dengan penelitian Harmanto (2012) yang menyebutkan bahwa paparan debu batu bata merah menyebabkan 56\% pekerja mengalami gangguan kapasitas fungsi paru-paru dan 34\% tidak mengalami gangguan kapasitas fungsi paru-paru.

Berdasarkan studi pendahuluan yang telah dilakukan pada perajin batu bata merah di sebuah proyek konstruksi, terlihat bahwa dalam proses kerjanya menghasilkan banyak debu dan hasil dari wawancara pada survey awal ditemukan bahwa 3 dari 5 orang perajin mengeluhkan sering batuk-batuk, bersin, dan sesak nafas saat bekerja.

Berdasarkan uraian dalam latar belakang masalah diatas, penulis tertarik untuk melakukan penelitian mengenai hubungan karakteristik individu dan paparan debu dengan gangguan kapasitas fungsi paru-paru pada perajin batu bata merah di Kabupaten Badung.

\section{METODE PENELITIAN}

Penelitian ini merupakan penelitian analitik dengan pendekatan kuantitatif dengan rancangan penelitian cross-sectional study untuk menganalisis karakteristik individu dan paparan debu dengan gangguan kapasitas fungsi paru-paru pada perajin batu bata merah di Kabupaten Badung. Jumlah sampel pada penelitian ini yaitu 42 orang perajin batu bata merah di Kabupaten Badung dengan teknik pengumpulan sampel yaitu consecutive sampling.

Pengumpulan data dilakukan dengan observasi wawancara dan pengukuran. Instrumen pengumpulan data yang digunakan adalah kuesioner yang mengacu pada penelitian Amerta (2019) untuk mengetahui karakteristik individu (umur, masa kerja, durasi kerja, kebiasaan merokok, dan penggunaan APD) serta pengukuran yaitu status gizi (IMT) dengan menggunakan timbangan berat badan dan microtoise, paparan debu menggunakan Personal Dust Sampler dan kapasitas fungsi paru menggunakan spirometer.

Data dianalisis secara univariabel dengan mendeskripsikan distribusi frekuensi dan proporsi dari masing-masing variabel. Analisis bivariabel dilakukan dengan uji chi-square dengan tingkat kepercayaan $\quad 95 \% \quad(\alpha=0,05) \quad$ untuk mengetahui hubungan antara satu variabel bebas dengan variabel tergantung. Analisis multivariabel dilakukan dengan uji multiple logistic regression dengan menyeleksi variabel yang memiliki nilai $\mathrm{p}<0,25$ untuk dianalisis secara bersama untuk mengetahui variabel dominan yang paling berpengaruh terhadap variabel tergantung. 
HASIL

Tabel 1. Analisis Univariabel

\begin{tabular}{|c|c|c|}
\hline Karakteristik Individu & Frekuensi (n) & Proporsi (\%) \\
\hline \multicolumn{3}{|l|}{ Umur } \\
\hline$\leq 30$ tahun & 7 & 16,67 \\
\hline$>30$ tahun & 35 & 83,33 \\
\hline \multicolumn{3}{|l|}{ Status Gizi (IMT) } \\
\hline Normal & 25 & 59,52 \\
\hline \multicolumn{3}{|l|}{ Tidak normal } \\
\hline Kurus & 4 & 9,52 \\
\hline Gemuk & 7 & 16,67 \\
\hline Obesitas & 6 & 14,29 \\
\hline \multicolumn{3}{|l|}{ Masa Kerja } \\
\hline$<10$ tahun & 10 & 23,81 \\
\hline$\geq 10$ tahun & 32 & 76,19 \\
\hline \multicolumn{3}{|l|}{ Durasi Kerja } \\
\hline Normal & 23 & 54,76 \\
\hline Lebih & 19 & 45,24 \\
\hline \multicolumn{3}{|l|}{ Kebiasaan Merokok } \\
\hline Tidak Merokok & 15 & 35,71 \\
\hline Merokok & 27 & 64,29 \\
\hline \multicolumn{3}{|l|}{ Penggunaan APD } \\
\hline Baik & 9 & 21,43 \\
\hline Buruk & 33 & 78,57 \\
\hline Paparan Debu & Frekuensi (n) & Proporsi (\%) \\
\hline$\leq \mathrm{NAB}$ & 6 & 14,29 \\
\hline$>\mathrm{NAB}$ & 36 & 85,71 \\
\hline Kapasitas Fungsi Paru-paru & Frekuensi (n) & Proporsi (\%) \\
\hline Normal & 3 & 7,14 \\
\hline \multicolumn{3}{|l|}{ Tidak Normal } \\
\hline Restriksi & 12 & 28,57 \\
\hline Obstruksi & 8 & 19,05 \\
\hline Mixed & 9 & 45,24 \\
\hline
\end{tabular}

Berdasarkan hasil analisis univariabel menunjukkan bahwa mayoritas responden berumur $>30$ tahun (83,33\%). Proporsi responden yang memiliki status gizi (IMT) normal yaitu 59,52\% dan gangguan yaitu $40,49 \%$, dimana terbagi menjadi 3 katagori yaitu kurus 23,5\%, gemuk 16,7\%, dan obesitas 14,3\%. Berdasarkan lamanya bekerja atau masa kerja, mayoritas responden dengan masa kerja $\geq 10$ tahun $(76,19 \%)$ dan sebagian besar responden bekerja dengan durasi kerja normal yaitu 
54,76\%. Berdasarkan kebiasaan merokok, mayoritas responden memiliki kebiasaan merokok yaitu $64,29 \%$ dengan rata-rata jumlah batang rokok yang dikonsumsi perhari yaitu 9 batang.

Sedangkan berdasarkan kebiasaan penggunaan APD, mayoritas responden memiliki kebiasaan penggunaan APD yang buruk yaitu tidak menggunakan APD atau hanya kadang-kadang menggunakan dan jika hanya dikontrol oleh atasan.
Bersasarkan paparan debu batu bata merah yang diterima responden, mayoritas menerima paparan debu melebihi NAB (>3 $\mathrm{mg} / \mathrm{m} 3$ ) yaitu $85,71 \%$ dengan paparan debu rata-rata yaitu 9,8 mg/ m3. Proporsi kapasitas fungsi paru- paru berdasarkan hasil penelitian menunjukkan bahwa 39 dari 42 responden mengalami gangguan kapasitas fungsi paru-paru yang terbagi menjadi 3 klasifikasi gangguan yaitu restrictive (28,57\%), obstructive $(19,05 \%)$ dan mixed restrictive obstructive $(45,24 \%)$.

Tabel 2. Analisis Bivariabel

\begin{tabular}{|c|c|c|c|c|c|c|}
\hline \multirow{2}{*}{ Katagori } & \multicolumn{2}{|c|}{ Kapasitas Fungsi Paru-paru } & \multirow[b]{2}{*}{ Total } & \multirow{2}{*}{ P'R } & \multirow{2}{*}{$95 \%$ CI } & \multirow{2}{*}{$\mathbf{p}$} \\
\hline & Normal & $\begin{array}{c}\text { Tidak } \\
\text { Normal }\end{array}$ & & & & \\
\hline \multicolumn{7}{|l|}{ Umur } \\
\hline$\leq 30$ tahun & $1(14,29 \%)$ & $6(85,71 \%)$ & $7(100 \%)$ & 1,1 & $0,80-1,50$ & 0,421 \\
\hline$>30$ tahun & $2(5,71 \%)$ & $33(94,29 \%)$ & $35(100 \%)$ & & & \\
\hline \multicolumn{7}{|l|}{ Status Gizi (IMT) } \\
\hline Normal & $2(8 \%)$ & $23(92 \%)$ & $25(100 \%)$ & 1,02 & $0,87-1,21$ & 0,793 \\
\hline Tidak normal & $1(5,89 \%)$ & $16(94,11 \%)$ & $17(100 \%)$ & & & \\
\hline \multicolumn{7}{|l|}{ Masa Kerja } \\
\hline$<10$ tahun & $1(10 \%)$ & $9(90 \%)$ & $10(100 \%)$ & 1,04 & $0,83-1,30$ & 0,687 \\
\hline$\geq 10$ tahun & $2(6,25 \%)$ & $30(93,75 \%)$ & $32(100 \%)$ & & & \\
\hline \multicolumn{7}{|l|}{ Durasi Kerja } \\
\hline Normal & $2(8,7 \%)$ & $21(9,3 \%)$ & $23(100 \%)$ & 1,03 & $0,88-1,22$ & 0,667 \\
\hline Lebih & $1(5,3 \%)$ & $18(94,7)$ & $19(100 \%)$ & & & \\
\hline \multicolumn{7}{|c|}{ Kebiasaan Merokok } \\
\hline Tidak Merokok & $1(6,67 \%)$ & $14(93,33 \%)$ & $15(100 \%)$ & 0,99 & $0,83-1,17$ & 0,929 \\
\hline Merokok & $2(7,4 \%)$ & $25(92,6 \%)$ & $27(100 \%)$ & & & \\
\hline \multicolumn{7}{|l|}{ Penggunaan APD } \\
\hline Baik & $2(22,2 \%)$ & $7(77,8 \%)$ & $9(100 \%)$ & 1,24 & $0,87-1,77$ & $0,04^{*}$ \\
\hline Buruk & $1(3,0 \%)$ & $32(96,9 \%)$ & $33(100 \%)$ & & & \\
\hline \multicolumn{7}{|l|}{ Paparan Debu } \\
\hline$\leq \mathrm{NAB}$ & $2(33,3 \%)$ & $4(66,7 \%)$ & $6(100 \%)$ & 1,45 & $0,82-2,57$ & $0,007^{*}$ \\
\hline$>\mathrm{NAB}$ & $1(2,78 \%)$ & $35(97,22 \%)$ & $36(100 \%)$ & & & \\
\hline
\end{tabular}


Berdasarkan analisis bivariat, variabel penggunaan APD dan paparan debu memiliki hubungan dengan gangguan kapasitas fungsi paru-paru $(p<0,05)$. Namun, tidak terdapat perbedaan proporsi gangguan kapasitas fungsi paru pada kelompok berisiko dan tidak berisiko pada variabel paparan debu. Hasil analisis menunjukkan penggunaan bahwa proporsi responden dengan penggunaan APD yang buruk 1,24 kali lebih berisiko meningkatkan gangguan kapasitas fungsi paru-paru dibandingkan dengan responden dengan penggunaan APD yang baik ( $\mathrm{p}=0,04 ; 95 \%$ $\mathrm{CI}=0,87-1,77$; PR 1,24).

Hasil analisis menunjukkan bahwa paparan debu yang melebihi NAB $(>3$ $\mathrm{mg} / \mathrm{m} 3$ ) meningkatkan risiko untuk terjadinya gangguan kapasitas fungsi paruparu 1,45 kali lebih tinggi dibandingkan dengan responden yang terpapar debu $\leq \mathrm{NAB}$ ( $\mathrm{p}=0,007 ; 95 \% \mathrm{CI}=0,82-2,57 ; \mathrm{PR}=1,45)$.

Tabel 3. Analisis Multivariabel

\begin{tabular}{|c|c|c|c|c|}
\hline \multirow{2}{*}{ Kapasitas Fungsi Paru-paru } & \multirow{2}{*}{ Adjusted OR } & \multicolumn{2}{|c|}{$95 \%$ CI for OR } & \multirow{2}{*}{$\mathrm{p}$} \\
\hline & & Lower Limit & Upper Limit & \\
\hline \multicolumn{5}{|l|}{ Paparan Debu } \\
\hline$\leq \mathrm{NAB}$ & 18,18 & 1,02 & 324,8 & $0,04^{*}$ \\
\hline$>\mathrm{NAB}$ & & & & \\
\hline \multicolumn{5}{|l|}{ Penggunaan APD } \\
\hline Baik & 9,56 & 0,52 & 172,3 & 0,12 \\
\hline Buruk & & & & \\
\hline
\end{tabular}

Hasil analisis multivariabel pada Tabel 3 menunjukkan bahwa variabel bebas yang paling berpengaruh meningkatkan risiko gangguan kapasitas fungsi paru-paru yaitu variabel paparan debu, namun signifikansi rendah $(\mathrm{OR}=18,18$; $95 \% \mathrm{CI}=1,02$ 324,8; $\mathrm{p}=0,004$ ).

Berdasarkan nilai odds ratio (OR), responden dengan paparan debu $>$ NAB memiliki risiko 18,18 kali lebih besar mengalami gangguan kapasitas fungsi paru- paru dibandingkan dengan responden dengan paparan debu $\leq \mathrm{NAB}$.

\section{DISKUSI}

Berdasarkan karakteristik umur, perajin yang memiliki umur $>30$ tahun, 94,9\% mengalami gangguan kapasitas fungsi paru- paru. Secara fisiologis, pertambahan umur akan mempengaruhi kemampuan organ- organ tubuh sehingga semakin bertambahnya umur, kemampuan organ- organ tubuh akan mengalami penurunan. Kapasitas fungsi paru-paru seseorang mulai menurun setelah berumur 30 tahun dan signifikan terjadi setelah umur 40 tahun sebesar 20\% (Apsari et al., 2018). Namun, hasil analisis uji chi-square menunjukkan bahwa variabel umur tidak berhubungan signifikan dengan gangguan kapasitas fungsi paru-paru $(p=0,0421)$. Hasil penelitian ini sejalan dengan penelitian yang dilakukan oleh Septyaningrum (2014) yang menyatakan bahwa tidak tidak ada hubungan antara umur dengan penurunan fungsi paru pada pekerja $(p=1,00)$. Namun, hasil berbeda ditemui pada penelitian Aini \& Saftarina 
(2017) yang menyebutkan bahwa terdapat hubungan yang signifikan antara umur dengan nilai kapasitas vital paru yang merupakan nilai penentu gangguan fungsi pada paru-paru $(p=0,00)$. Menurut pandangan peneliti, perbedaan hasil tersebut bisa terjadi karena umur bukan satu-satunya faktor penentu gangguan kapasitas fungsi paru-paru, namun bisa disebabkan oleh banyak faktor lain seperti masa kerja yang sebentar, paparan debu minimum, kebiasaan rutin berolahraga dan penggunaan APD yang baik saat bekerja.

Berdasarkan karakteristik status gizi (IMT), perajinyang memiliki status gizi tidak normal yang memiliki gangguan kapasitas fungsi paru-paru sebesar 94,11\%. Namun, berdasarkan analisis bivariabel menunjukkan bahwa status gizi (IMT) tidak berhubungan signifikan dengan gangguan kapasitas fungsi paru-paru $(p=0,793)$. Hal ini sejalan dengan Ardam (2015) yang menyatakan bahwa tidak terdapat hubungan antara status gizi dengan gangguan faal paru-paru $(p=0,39)$. Penelitian lain juga menyatakan bahwa tidak ada hubungan antara status gizi (IMT) dengan kapasitas faal paru-paru $(\mathrm{p}=0,19)$ (Luthfi et al., 2014). Namun, penelitian lain menyatakan bahwa IMT berpengaruh terhadap gangguan faal paruparu, dimana orang yang kurus cenderung memiliki kapasitas fungsi paru- paru normal dan semakin besar indeks massa tubuh (IMT) seseorang, maka cenderung untuk mengalami gangguan faal paru-paru (Hikmayanti, 2018). Perbedaan hasil tersebut bisa disebabkan oleh perajin yang memiliki status gizi (IMT) tidak normal memiliki pola hidup yang sehat seperti tidak merokok, kebiasaan berolahraga dan pola makan yang sehat sehingga dapat menyebabkan kapasitas fungsi paru-paru menjadi normal.

Hasil penelitian menunjukkan bahwa mayoritas perajin memiliki masa kerja lama ( $\geq 10$ tahun) dan sebesar 93,75\% perajin yang memiliki masa kerja lama mengalami gangguan kapasitas fungsi paru-paru. Berdasarkan analisis bivariabel, masa kerja tidak berhubungan signifikan dengan gangguan kapasitas fungsi paru-paru $(p=0,687)$. Penelitian ini sejalan dengan Sholihati et al., (2017) yang menyatakan bahwa tidak ada hubungan antara masa kerja dengan gangguan fungsi paru-paru. Selain itu penelitian Awang et al., (2017) menyatakan bahwa masa kerja tidak memiliki hubungan yang bermakna dengan gangguan fungsi paruparu ( $p=0,233)$. Namun, hasil berbeda ditemukan pada penelitian Fakmi (2012) yang menyatakan bahwa terdapat hubungan antara masa kerja dengan kapasitas fungsi paru-paru (FVC dan $\mathrm{FEV}_{1}$ ) dengan nilai $\mathrm{p}=0,01$ dan 0,019. Semakin lama masa kerja maka semakin banyak pekerja menerima paparan bahaya yang ditimbulkan pada lingkungan kerja (Suma'mur, 2013). Namun hasil pada penelitian ini menunjukkan sebaliknya, hal ini dapat disebabkan oleh pekerja dengan masa kerja lama (> 10 tahun) menggunakan APD berupa masker dengan baik saat bekerja sehingga dapat mengurangi efek paparan debu yang ada pada lingkungan kerja.

Berdasarkan durasi kerja, diketahui bahwa mayoritas respondem memiliki durasi kerja normal (8jam/hari) dan 91,3\%nya memiliki gangguan kapasitas fungsi paru-paru. Berdasarkan hasil analisis 
uji chi-square menunjukkan bahwa variabel durasi kerja tidak berhubungan signifikan dengan gangguan kapasitas fungsi paruparu $(p=0,421)$. Penelitian ini sejalan dengan Mengkidi et al., (2006) yang menyatakan bahwa lama paparan atau durasi kerja tidak berhubungan dengan gangguan kapasitas paru-paru $(p=0,960)$. Namun, hasil berbeda dinyatakan oleh Apsari et al., (2018) yang menyatakan bahwa durasi kerja yang berlebih terbukti sebagai faktor yang berhubungan dan cenderung sebagai risiko terhadap gangguan fungsi paru-paru $(\mathrm{p}=0,046)$. Hasil pada penelitian ini tidak sesuai dengan teori bahwa semakin lama pekerja terpapar oleh paparan debu maka akan semakin memperbesar risiko terjadinya gangguan fungsi paru-paru. Menurut pandangan peneliti, hal ini dapat disebabkan karena lamanya durasi kerja tidak menutup kemungkinan bahwa paparannya juga semakin besar, sehingga pekerja dengan durasi kerja lebih bisa menunjukkan hasil kapasitas fungsi paru-paru yang normal apabila memiliki masa kerja yang pendek, paparan debu yang sedikit atau memiliki kebiasaan penggunaan APD berupa masker yang baik.

Berdasarkan karakteristik kebiasaan merokok, 92,6\% responden yang memiliki kebiasaan merokok mengalami ganguan kapasitas fungsi paru-paru. Hasil analisis uji chi-square menunjukkan bahwa variabel kebiasaan merokok tidak berhubungan signifikan dengan gangguan kapasitas fungsi paru-paru $(p=0,929)$. Hasil ini sejalan dengan penelitian Apsari et al., (2018) yang menyatakan bahwa kebiasaan merokok tidak terbukti sebagai faktor yang berhubungan dengan gangguan fungsi paru namun cenderung menjadi faktor protektif ( $p=0,139)$. Namun, hasil penelitian berbeda ditunjukkan oleh Sholihah \& Tualeka (2015) yang menyatakan bahwa terdapat hubungan antara kondisi faal paru pekerja dengan kebiasaan merokok pekerja. Penelitian lain di Amerika menunjukkan hasil adanya hubungan dose respon antara kebiasaan merokok dengan dan rendahnya level FEV1/FVC dan FEF 25-75\%. Jumlah konsumsi rokok sebanyak 10 batang perhari ditemukan berhubungan dengan penurunan FEF $25-75 \%$ dibanding orang yang tidak merokok dan berpengaruh terhadap gangguan kapasitas fungsi paru obstructive (Gold et al., 2005). Menurut pandangan penulis, kebiasaan merokok tidak berhubungan dengan gangguan kapasitas fungsi paru-paru karena disebabkan oleh banyak faktor lain seperti lama durasi merokok, jumlah batang rokok, penggunaan APD saat bekerja dan masa kerja yang pendek.

Berdasarkan penggunaan APD, $78,57 \%$ perajin memiliki kebiasaan penggunaan APD yang buruk yaitu kadang-kadang menggunakan APD saat bekerja ataupun jika hanya dikontrol oleh atasan. Hasil analisis uji chi-square menyebutkan bahwa terdapat hubungan yang signifikan antara penggunaan APD dengan gangguan kapasitas fungsi paruparu $(p=0,004)$. Adanya hubungan antara penggunaan APD dengan kapasitas fungsi paru-paru sejalan dengan penelitian yang dilakukan oleh Nazikhah et al., (2017) yang menyatakan bahwa terdapat hubungan antara pemakaian APD $(p=0,040)$ dengan gangguan faal paru pada pekerja perusahaan galangan kapal. Selain itu, penelitian yang dilakukan oleh Awang et 
al., (2017) juga menyatakan bahwa terdapat hubungan yang signifikan antara penggunaan APD dengan gangguan fungsi paru-paru $(p=0,00)$. Namun, penelitian lain menyebutkan bahwa tidak terdapat hubungan antara pemakaian APD berupa masker dengan kelainan paru $(p=0,52)$ (Luthfi et al., 2014). Penggunaan APD yaitu masker yang digunakan secara rutin berhubungan dengan gangguan kapasitas fungsi paru-paru karena dapat meminimalkan jumlah debu yang terhirup hidung dan mengurangi efek dari paparan debu pada lingkungan kerja sehingga mengurangi risiko terjadinya gangguan kapasitas fungsi paru-paru.

Berdasarkan paparan debu, $85,71 \%$ perajin terpapar debu batu bata merah melebihi NAB (>3 mg/m ${ }^{3}$ ) yaitu dengan rata- rata paparan debu sebesar 9,8 $\mathrm{mg} / \mathrm{m}^{3}$. Berdasarkan hasil penelitian, perajin dengan paparan debu $>\mathrm{NAB}$ yang memiliki gangguan kapasitas fungsi paruparu sebanyak $97,22 \%$ dan hanya 2,78\% yang memiliki kapasitas fungsi paru-paru normal. Sesuai dengan hasil uji chi-square menyebutkan bahwa tidak terdapat perbedaan proporsi gangguan kapasitas fungsi paru pada kelompok berisiko dan tidak berisiko. Perajin dengan paparan debu yang >NAB dapat meningkatkan risiko untuk terjadinya kapasitas fungsi paru-paru tidak normal 1,45 kali lebih tinggi dibandingkan dengan perajin dengan paparan debu yang $\leq \mathrm{NAB}$ (OR=1,45; 95\% CI=0,82-2,57; p=0,007). Hal ini sejalan dengan penelitian Wulansari (2019) yang menyatakan bahwa tidak terdapat hubungan signifikan antara paparan debu dengan gangguan faal paruparu $(p=0,46)$. Namun, penelitian lain yaitu
Ardam (2015) yang menunjukkan bahwa terdapat hubungan yang positif dan kuat antara paparan debu dengan terjadinya gangguan faal paru, dimana semakin tinggi paparan debu di lingkungan kerja, maka semakin tinggi pula persentase pekerja yang mengalami gangguan faal paru $(p=0,00)$. Penelitian lain juga menyebutkan bahwa terdapat hubungan antara paparan debu dengan status faal paru $(p<0,05)$ yang dapat menyebabkan gangguan faal paru (Helmy, 2019). Berdasarkan teori, semakin banyak kadar debu di lingkungan kerja maka akan memperbesar risiko terjadinya gangguan kapasitas fungsi paru-paru. Kadar debu yang terkandung dalam udara menyebabkan paparan debu menjadi tinggi sehingga semakin banyak debu yang terhirup hidung dan dapat menyebabkan penyakit pada sistem pernapasan.

Hasil analisis multivariabel menunjukkan bahwa variabel yang paling berpengaruh meningkatkan risiko gangguan kapasitas fungsi paru-paru yaitu variabel paparan debu. Berdasarkan hasil analisis, variabel paparan debu memiliki nilai $\quad(A O R=18,18 ; \quad 95 \% \quad C I=1,02-324,8$; $\mathrm{p}=0,004)$. Hal ini menunjukkan bahwa paparan debu secara statistik berpengaruh terhadap gangguan kapasitas fungsi paruparu karena memiliki nilai $\mathrm{p}<0,05$ namun signifikansi rendah. Hal ini disebabkan karena besar sampel penelitian yang sedikit sehingga menyebabkan rentang CI menjadi besar dan signifikansi hasil penelitian menjadi rendah. Jika dilihat dari nilai AOR, reponden dengan paparan debu melebihi $\mathrm{NAB}\left(>3 \mathrm{mg} / \mathrm{m}^{3}\right.$ ) meningkatkan risiko gangguan kapasitas fungsi paru-paru 18,18 kali lebih besar daripada perajin dengan paparan debu kurang dari NAB $(\leq 3$ 
$\left.\mathrm{mg} / \mathrm{m}^{3}\right)$. Penelitian ini sejalan dengan penelitian yang dilakukan oleh Yulaekah (2007) yang menyatakan bahwa paparan debu terhirup berhubungan signifikan terhadap gangguan fungsi paru $(p=0,007)$ serta perajin dengan paparan debu terhirup yang melebihi NAB (>3 $\left.\mathrm{mg} / \mathrm{m}^{3}\right)$ mempunyai risiko untuk mengalami gangguang fungsi paru-paru 5,127 kali lebih besar dibandingkan dengan perajin yang bekerja di tempat kerja dengan konsentrasi debu terhirup di bawah NAB ( $\left.\leq 3 \mathrm{mg} / \mathrm{m}^{3}\right)(95 \% \mathrm{CI}=1,574-16,706)$.

Dalam hal penggunaan APD didaptkan nilai (AOR=9,56; 95\% CI=0,52172,3; $\mathrm{p}=0,12$ ). Hal ini menunjukkan bahwa variabel penggunaan APD tidak berhubungan secara signifikan terhadap gangguan kapasitas fungsi paru-paru karena memiliki nilai $p>0,05$. Namun, variabel penggunaan APD dapat meningkatkan risiko terjadinya gangguan kapasitas fungsi paru-paru 9,56 kali lebih besar pada perajin dengan penggunaan APD yang buruk daripada perajin dengan penggunaan APD baik. Hasil penelitian ini sejalan dengan penelitian Awang et al., (2017) yang menyatakan bahwa tidak selalu menggunakan APD (masker) memiliki hubungan bermakna dengan gangguan fungsi paru-paru yaitu berisiko 12,15 kali lebih besar dibandingkan dengan selalu menggunakan APD (masker) (AOR=12,15; 95\% CI=1,44-102,62; $\mathrm{p}=0,022$ ).

\section{SIMPULAN}

Berdasarkan karakteristik individu, sebagian besar perajin berumur $>30$ tahun, memiliki status gizi (IMT) normal, masa kerja $\geq 10$ tahun, durasi kerja normal (8 jam/hari), memiliki kebiasaan merokok, dan penggunaan APD yang buruk. Sebagian besar perajin terpapar debu > $\mathrm{NAB}\left(3 \mathrm{mg} / \mathrm{m}^{3}\right)$ dengan rata-rata $9,8 \mathrm{mg} / \mathrm{m}^{3}$ dan memiliki gangguan kapasitas fungsi paru-paru (92,86\%) dengan jenis gangguan yaitu mixed restrictive obstructive. Analisis bivariabel membuktikan bahwa terdapat hubungan antara penggunaan APD dengan gangguan kapasitas fungsi paru-paru $(p=0,04)$ dan pada variabel paparan debu, tidak terdapat perbedaan proporsi gangguan kapasitas fungsi paru-paru pada kelompok responden berisiko dan tidak berisiko $(\mathrm{p}=0,007)$. Tidak terdapat hubungan yang antara umur $(\mathrm{p}=0,421)$, status gizi (IMT) $(p=0,793)$, masa kerja $(p=0,687)$, durasi kerja $(p=0,667)$, kebiasaan merokok $(p=0,929)$ dengan gangguan kapasitas fungsi paruparu. Berdasarkan analisis multivariabel, paparan debu merupakan variabel yang paling berpengaruh meningkatkan risiko gangguan kapasitas fungsi paru-paru namun signifikansi rendah (AOR=18,18; $95 \% \mathrm{CI}=1,02-324,8)$.

\section{SARAN}

Bagi perajin dan kepala mandor atau manajemen diharapkan untuk melakukan pengendalian sesuai dengan segitiga hirarki pengendalian seperti: (1) Teknik atau perancangan yaitu menggunakan metode basah dalam proses pemotongan batu bata merah dengan memperhatikan arah mata angin untuk mengurangi paparan debu; Administrasi yaitu melakukan pembagian shift kerja sesuai dengan jam kerja pada peraturan untuk mengurangi paparan debu, membuat peraturan agar perajin tidak merokok pada saat bekerja sehingga bisa mengurangi jumlah konsumsi rokok, 
dan melakukan pemeriksaan kesehatan secara berkala; (3) APD yaitu penggunaan masker saat bekerja dengan baik.

$\begin{array}{rll}\text { Bagi } & \text { peneliti } & \text { selanjutnya } \\ \text { diharapkan } & \text { untuk } & \text { melakukan }\end{array}$
pemeriksaan riwayat kesehatan perajin agar hasil penelitian yang didapatkan memang benar hubungan akibat dari paparan debu dan data yang didapatkan tidak bias serta memperhatikan teknik pengambilan sampel yakni memakai teknik survey terhadap proyek pembangunan gapura yang melibatkan pekerja lebih banyak.

\section{DAFTAR PUSTAKA}

Abdurrohmansyah, Adha, I., \& Ali, H. (2015). Studi Kuat Tekan Batu Bata Menggunakan Bahan Additive (Abu Sekam Padi, Abu Ampas Tebu \& Fly Ash) Berdasarkan Spesifikasi Standar Nasional Indonesia (SNI). JRSDD, 3(3), 2303-2314.

Aini, S. Q., \& Saftarina, F. (2017). Hubungan Karakteristik Individu dengan Nilai Kapasitas Vital Paru Pekerja di PT. Bukit Asam (Persero ) Tbk Unit Tarahan Lampung. Jurnal Agromed Unila, 4(2), 244-250.

Amerta, W. P. (2019). Hubungan Paparan Debu dengan Kapasitas Fungsi Paru Perajin Batu Paras Di Desa Ketewel, Sukawati, Gianyar. [Skripsi]. Bali: Universitas Udayana.

Anugrah, Y. (2014). Faktor-Faktor yang Berhubungan dengan Kapasitas Vital Paru pada Pekerja Penggilingan Divisi Batu Putih di PT. Sinar Utama Karya. Unnes Journal of Public Health, 3(1), 1-9.

Apsari, L., Budiyono, \& Setiani, O. (2018).
Hubungan Paparan Debu Terhirup dengan Gangguan Fungsi Paru pada Pekerja Pertambangan Pasir dan Batu Perusahaan X Rowosari Kota Semarang. Jurnal Kesehatan Masyarakat (e-Journal), 6(4), 463-475. Ardam, K. A. Y. (2015). Hubungan Paparan

Debu dan Lama Paparan dengan Gangguan Faal Paru Pekerja Overhaul Power Plant. The Indonesian Journal of Occupational Safety and Health, 4(2), 155166.https://doi.org/10.20473/ijosh.v4i 2.2 015.155-166

Awang, M. H., Sulistomo, A., \& H, M. J. D. (2017). Gambaran Fungsi Paru dan Faktor-Faktor yang Berhubungan pada Pekerja Terpapar Debu Bagasse di Pabrik Gula X Kabupaten Lampung Tengah. Indonesia Medical Association, 67(10), 576-583.

Fakmi, T. (2012). Hubungan Masa Kerja dan Penggunaan APD dengan Kapasitas Fungsi Paru pada Pekerja Tekstil Bagian Ring Frame Spinning I di PT. X Kabupaten Pekalongan. Jurnal Kesehatan Masyarakat, 1(2), 828-835.

Gold, D. R., Wang, X., Wypij, D., Speizer, F. E., Ware, J. H., \& Dockery, D. W. (2005). Effects of Cigarette Smoking on Lung Function in Adolescent Boys and Girls. The New England Journal Medicine, 335(13), 931-937.

Handari, M. C., Sugiharto, \& Pawenang, E. T. (2018). Karakteristik Pekerja dengan Kejadian Gangguan Fungsi Paru pada Pekerja Dipo Lokomotif. Higeia Journal of Public Health Research and Development, 1(3), 4556. 
Harmanto, A. (2012). Pengaruh Paparan Debu Terhadap Kapasitas Fungsi Paru Pekerja Pembakaran Batubata di Kecamatan Kebakramat Karanganyar. [Skripsi]. Surakarta: Universitas Sebelas Maret.

Helmy, R. (2019). Hubungan Paparan Debu dan Karakteristik Individu dengan Status Faal Paru Pedagang di Sekitar Kawasan Industri

Gresik. Jurnal Kesehatan Lingkungan, 11(2), 132-140. https://doi.org/10.2 0473/jkl.v11i2.2019.1 50-157

Hikmayanti, U. (2018). Studi Faal Paru dan Faktor Determinannya pada Pekerja di Industri Sawmill. The Indonesian Journal of Occupational Safety and Health, 7(3), 357-367. Luthfi, A., Yunus, F., Prasenohadi, \& Prihartono, J. (2014). Faktor-faktor yang Mempengaruhi Faal Paru Polisi Lalu Lintas di Wilayah Jakarta Timur. Jurnal Respirologi Indonesia, 34(2), 87-94.

Mengkidi, D., Nurjazuli, \& Sulistiyani. (2006). Gangguan Fungsi Paru dan Faktor- faktor yang Mempengaruhinya pada Karyawan PT.Semen Tonasa Pangkep Sulawasi Selatan. Jurnal Kesehatan Lingkungan Indonesia, 6(1), 59-64. https://doi.org/10.14710/JKLI.5.2.59 64.

Mohammadien, H. A., Hussein, M. T., \& El- Sokkary, R. T. (2013). Effects of Exposure to Flour Dust on Respiratory Symptoms \& Pulmonary Function of Mill Workers. Egyptian Journal of Chest Diseases and Tuberculosis, 62(4), 745-753.

https://doi.org/10.1016/j.ejcdt.2013.09
.007

Nazikhah, A., R, B. M., \& Disrinama, A. M. (2017). Analisis Faktor-Faktor yang Mempengaruhi Gangguan Faal Paru pada Perusahaan Galangan Kapal. Politeknik Perkapalan Negeri Surabaya, (2581-2653).

Pemerintah Indonesia. Peraturan Bupati Badung Nomor 9 Tahun 2019 tentang Perubahan Atas Peraturan Bupati Nomor 43 Tahun 2018 Tentang Pedoman Pemberian Hibah.

Pemerintah Indonesia. Peraturan Presiden Republik Indonesia No. 7 Tahun 2019 Tentang Penyakit Akibat Kerja.

Peraturan Menteri Ketenagakerjaan Republik Indonesia Nomor 5 Tahun 2018 tentang Keselamatan dan Kesehatan Kerja Lingkungan Kerja. Septyaningrum, M. (2014). Hubungan Paparan Debu Kapur dengan Penurunan Fungsi Paru pada Tenaga Kerja PT. Putri Indah Pertiwi, Desa Pule, Gedong, Pracimantoro, Wonogiri. Implementation Science, 39(1), 1-15. https://doi.org/10.4324/ 9781315853178.

Sholihah, M., \& Tualeka, A. R. (2015). Studi Faal Paru dan Kebiasaan Merokok pada Pekerja yang TerpaparDebu pada Perusahaan Konstruksi di Surabaya. The Indonesian Journal of Occupational Safety and Health, 4(1), 110. https://doi.org/10.20473/ijosh.v4i1 .2015. 1-10

Sholihati, N., Suhartono, \& D, N. A. Y. (2017). Hubungan Masa Kerja dan Penggunaan APD dengan Gangguan Fungsi Paru pada Penyapu Jalan di Ruas Jalan Tinggi Pencemaran Kota Semarang. Jurnal 
Kesehatan Masyarakat, 5(5), 776-789.

Suma'mur, P. (2013). Higiene Perusahaan dan Kesehatan Kerja (HIPERKES). Jakarta: Agung Seto.

Wulansari, D. T. (2019). Analisis Hubungan Karakteristik Pekerja dan Paparan Debu Kayu dengan Status Faal Paru Pekerja Bagian Jumping Saw Industri Kayu di Banyuwangi. Jurnal Kesehatan
Lingkungan, 11(2), 99-107. https:// doi.org/10.20473/jkl.v11i2.2019.99107

Yulaekah, S. (2007). Pajanan Debu Terhirup dan Gangguan Fungsi Paru pada Pekerja Industri Batu Kapur (Studi Di Desa Mrisi Kecamatan Tanggungharjo Kabupaten Grobogan). [Tesis]. Semarang: Universitas Diponegoro. 